GRASAS Y ACEITES 69 (1)

January-March 2018, e231

ISSN-L: 0017-3495

https://doi.org/10.3989/gya.0776171

\title{
Extracellular laccase production and phenolic degradation by an olive mill wastewater isolate
}

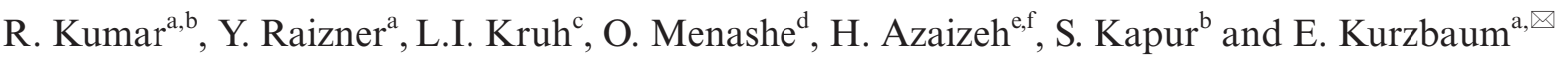 \\ ${ }^{\mathrm{a}}$ Shamir Research Institute, University of Haifa, P.O. Box 97, Qatzrin 12900, Israel \\ ${ }^{b}$ Department of Biological Science, Birla Institute of Technology and Science, Pilani, Hyderabad Campus, Hyderabad 500078, India \\ ${ }^{c}$ Department of Biotechnology Engineering, ORT Braude College, P.O. Box 78, Karmiel 21982, Israel \\ ${ }^{\mathrm{d}}$ Water Industry Engineering Department, Achi Racov Engineering School, Kinneret College on the Sea of Galilee, D.N. Emek \\ Ha'Yarden 15132, Israel \\ ${ }^{\mathrm{e}}$ Institute of Applied Research, University of Haifa, The Galilee Society, P.O. Box 437, Shefa-Amr, 20200, Israel \\ ${ }^{\mathrm{f}}$ Tel-Hai College, Department of Environmental Science, Upper Galilee 12208, Israel \\ ${ }^{\circledR}$ Corresponding author: ekurzbaum@univ.haifa.ac.il
}

Submitted: 04 July 2017; Accepted: 03 October 2017

\begin{abstract}
SUMMARY: Olive mill wastewater (OMWW) presents a challenge to the control of effluents due to the presence of a high organic load, antimicrobial agents (monomeric-polymeric phenols, volatile acids, polyalcohols, and tannins), salinity and acidity. In this study, the production of extracellular laccase, monomeric or polymeric phenol, from an OMWW isolate based on its ability to biodegrade phenols and gallic acid as a model of phenolic compounds in OMWW was investigated. Phylogenetic analysis of the 16S RNA gene sequences identified the bacterial isolate (Acinetobacter REY) as being closest to Acinetobacter pittii. This isolate exhibited a constitutive production of extracellular laccase with an activity of 1.5 and $1.3 \mathrm{U} \mathrm{ml} / \mathrm{L}$ when supplemented with the inducers $\mathrm{CuSO}_{4}$ and $\mathrm{CuSO}_{4}+$ phenols, respectively. Batch experiments containing minimal media supplemented with phenols or gallic acid as the sole carbon and energy source were performed in order to characterize their phenolic biodegradability. Acinetobacter REY was capable of biodegrading up to $200 \mathrm{mg} / \mathrm{L}$ of phenols and gallic acid both after $10 \mathrm{~h}$ and $72 \mathrm{~h}$, respectively.
\end{abstract}

KEYWORDS: Acinetobacter REY; Biodegradation; Extracellular laccase; Olive mill waste water; Phenolic compounds

RESUMEN: Producción de lacasa extracelular y degradación de compuestos fenólicos mediante un aislado de aguas residuales de almazara. Las aguas residuales de almazara (OMWW) presentan un desafío a los efluentes debido a la presencia de una carga orgánica alta, agentes antimicrobianos (fenoles monoméricos y poliméricos, ácidos volátiles, polialcoholes y taninos), salinidad y acidez. En este estudio, se investigó la producción de lacasa extracelular a partir de un aislado de OMWW basado en su capacidad para biodegradar fenol y ácido gálico como modelo de compuestos fenólicos en OMWW. El análisis filogenético de las secuencias del gen de ARN 16S identifico el aislado bacteriano (Acinetobacter REY) como el más cercano a Acinetobacter pittii. Este aislado exhibió producción constitutiva de lacasa extracelular con una actividad de 1.5 y $1.3 \mathrm{U} \mathrm{mL} / \mathrm{L}$ cuando se suplemento con los inductores $\mathrm{CuSO} 4$ y CuSO $4+$ fenol, respectivamente. Se realizaron experimentos en lotes que contenían medios mínimos suplementados con fenol o acido gálico como la única fuente de carbono y energía con el fin de caracterizar su biodegradabilidad fenólica. Acinetobacter REY fue capaz de biodegradar hasta $200 \mathrm{mg} / \mathrm{L}$ de fenol y acido gálico después de 10 y $72 \mathrm{~h}$, respectivamente.

PALABRAS CLAVE: Acinetobacter REY; Aguas residuales de almazara; Biodegradación; Compuestos fenólicos; Lacasa de células extracelulares

ORCID ID: Kumar R https://orcid.org/0000-0001-6929-9176, Raizner Y https://orcid.org/0000-0001-7710-5845, Kruh LI https://orcid.org/0000-0002-8342-7653, Menashe O https://orcid.org/0000-0001-7368-0754, Azaizeh H https://orcid.org/0000-0002-0311-1158, Kapur S https://orcid.org/0000-0002-1941-9288, Kurzbaum E https://orcid. org/0000-0002-8258-9407

Citation/Cómo citar este artículo: Kumar R, Raizner Y, Kruh LI, Menashe O, Azaizeh H, Kapur S, Kurzbaum E. 2107. Extracellular laccase production and phenolic degradation by an olive mill wastewater isolate. Grasas Aceites 69 (1), e231. https://doi.org/10.3989/gya.0776171

Copyright: (C2018 CSIC. This is an open-access article distributed under the terms of the Creative Commons Attribution 4.0 International (CC BY 4.0) License. 


\section{INTRODUCTION}

Approximately $5.4 \times 10^{6}$ tons of olive mill wastewater (OMWW) are produced annually worldwide. OMWW is a recalcitrant waste that has high phenolic, lipid, organic acid and tannin contents. The phenolics are present as a mono/polymeric aromatic mix which gives the OMWW its brownish color. Uncontrolled disposal of OMWW is becoming a serious environmental problem, due to its high organic content which consists mainly of antimicrobial and phytotoxic phenolic compounds (Ruiz et al., 2002).

The importance of using enzymes in industrial and agricultural waste treatment has increased in recent years. Laccase (benzenediol: oxygen oxidoreductases, copper-containing polyphenol oxidase EC1.10.3.2) is one, inter alia, which is currently the focus of much attention because of its diverse applications. These include dye decolorization, pulp bleaching, waste detoxifications and bioremediation of environmental pollutants, synthesis of organics or electrocatalysis (Kunamneni et al., 2008). Laccases can catalyze a broad range of phenolic and nonphenolic compounds without any requirement other than oxygen. This makes them very useful in biotechnological applications. Laccases catalyze phenols such as ortho- and para-diphenols, aminophenols, polyphenols, methoxy-substituted phenols, 2,6-dimethoxyphenol, phenolic acids, polyamines, aromatic amines, phenylene diamine, lignins, aryl diamines, as well as several other nonphenolic compounds (hydroquinone, guaiacol) and some inorganic ions (Atalla et al., 2013).

Fungal laccases have been widely studied for the detoxification of pollutants in the environment, revaluation of industrial wastes and wastewater treatment (Bertand et al., 2013). However, little is known about the use of bacterial laccases for these applications. Recent studies showed the extracellular production of laccase by several bacterial strains, including Pseudomonas putida F6, P. putida MTCC 7525, Pseudomonas sp. LBC1, P. putida LUA15.1, Escherichia coli, Bacillus halodurans, B. subtilis SF, Bacillus sp. HR03, Azospirillum lipoferum, P. desmolyticum NCIM 2112, B. pumilus and B. subtilis WP1 (Kuddus et al., 2013; Muthukumar and Murugan, 2014; Verma et al., 2016). Most bacterial laccases are stable, highly thermo-tolerant and maintain their activity under neutral to alkaline conditions. They are less dependent on metal ions and less susceptible to inhibitory agents than fungal laccases (Baldrian and Šnajdr, 2006). Bacterial laccases therefore continue to draw attention as an alternative to chemical processes which would enable the industry to meet the increasingly stringent environmental requirements of reducing the environmental xenobiotic load. For example, several studies showed the use of laccase from different bacteria for detoxifying a wide range of pollutants. This has made them useful in many industries, including wine, paper, pulp and textile industries. Other applications, including biobleaching, enhanced saccharification and biocatalytic arylation, were also reported (Sondhi et al., 2015; Suljić et al., 2015). The use of laccase for treating OMWW may present a great opportunity for successful biological treatment by overcoming the presence of the major obstacle: phenolics. Eliminating or significantly reducing the major anti-microbial agent and oxygen consumer allows for a more cost-effective treatment solution for OMWW. It is therefore possible that the OMWW flora contains isolates that have already developed resistance to this virulent medium, and it may be possible to exploit their ability to produce the target enzyme, laccase.

Extraction of extracellular enzymes from industrial and agricultural waste isolates has great potential for reducing the pollutant load on the environment. The aim of the present study was therefore to isolate a bacterium from OMWW based on its ability to biodegrade phenols and gallic acid as a model for phenolic compound biodegradation as a pre-treatment or as an additive treatment for use in OMWW remediation. This isolate, which originated from an OMWW, was screened for the production of extracellular enzymes, including amylase, protease, lipase and laccase. Additional information on the potential of bacterial laccases for wastewater treatment is discussed.

\section{MATERIALS AND METHODS}

\subsection{OMWW characterization and sampling}

The OMWW used in this work was collected from Maghar, the Galilee region, Israel. The main properties of the OMWW used for bacterial isolation were determined as described in standard methods (Rice 2012) and are reported in Table 1. The phenolic content of the OMWW was characterized as described by Azaizeh et al., (2012) and is shown in Figure 1.

\subsection{Isolation of phenolic-degrading bacteria and identification of the isolate by 16s rRNA analysis}

Microorganisms were isolated by their ability to grow on phenols as the sole carbon source, as described in detail by Kurzbaum et al., (2010). After incubation at $37{ }^{\circ} \mathrm{C}$ for $24 \mathrm{~h}$, the fastest growing colonies were isolated using several isolation cycles. The fastest growing colony was then identified by $16 \mathrm{~S}$ rRNA analysis. In order to verify the phylogenetic affiliation of the selected isolate, a single colony was collected for DNA isolation and subjected to PCR analysis using primers targeting the $16 \mathrm{~S}$ rRNA gene [27F (AGAGTTTGATCMTGGCTCAG) and 
1513R (ACGGYTACCTTGTTACGACTT)], by the direct colony PCR method as previously described (Iasur-Kruh et al., 2011). PCR $(25 \mu \mathrm{L})$ contained $10 \mu \mathrm{L}$ of Apex ${ }^{\mathrm{TM}} \mathrm{Taq}$ DNA Polymerase Master Mix (Genorama, Tartu, Estonia), 5 pmol of each primer, $12.5 \mu \mathrm{L}$ DDW and $1 \mu \mathrm{L}$ DNA template. The PCR procedure was as follows: DNA was denatured at $95^{\circ} \mathrm{C}$ for $5 \mathrm{~min}$, followed by 30 cycles at $95^{\circ} \mathrm{C}$ for 30 sec each, $58^{\circ} \mathrm{C}$ for $30 \mathrm{sec}$ and $72^{\circ} \mathrm{C}$ for $1 \mathrm{~min}$, followed by $5 \mathrm{~min}$ at $72{ }^{\circ} \mathrm{C}$. The PCR product was sequenced by Hy-labs (Rehovot, Israel). A neighbor-joining (NJ) tree based on nearly complete 16S rRNA gene sequences showed the phylogenetic position of the OMWW isolate to be a closely related species from the genus Acinetobacter. Multiple alignments were computed using MUSCLE (Edgar, 2004) and the NJ tree was calculated with Kimura 2 parameters model in MEGA7 (Kumar et al., 2016) with 1000 bootstrap replicates. Moraxella lacunata ATCC 17967 was used as an out group.

\subsection{Sequence accession}

The sequence of the bacterium isolated from the OMWW was deposited in GenBank, NCBI (KY828225).

TABLE 1. Different parameters of crude OMWW and s-TP fraction.

\begin{tabular}{lcc}
\hline Parameter & Crude OMWW & Fraction s-TP \\
\hline $\mathrm{pH}$ & $4.64 \pm 0.12$ & $2.99 \pm 0.05$ \\
Total COD & $133519 \pm 4512$ & $3333 \pm 663$ \\
TSS & $6990 \pm 180$ & $129.7 \pm 12.8$ \\
Total Phenol & $3250 \pm 180$ & $157.9 \pm 4.3$ \\
TKN & $280.5 \pm 22$ & $1.12 \pm 0.15$ \\
\hline
\end{tabular}

All units are expressed in $\mathrm{mg} / \mathrm{L}$, except $\mathrm{pH}$.

\pm indicates standard deviation

\subsection{Inoculum preparation for degradation studies}

The selected pure colonies were aseptically transferred to $250 \mathrm{ml}$ Erlenmeyer flasks containing a mineral salt medium (MSM) comprised of the following salts $(\mathrm{g} / \mathrm{L}): \mathrm{NaHPO}_{4} \cdot 12 \quad \mathrm{H}_{2} \mathrm{O}-6.15 \mathrm{~g} / \mathrm{L}, \mathrm{KH}_{2} \mathrm{PO} 4-1.52 \mathrm{~g} / \mathrm{L}$, $\left(\mathrm{NH}_{4}\right)_{2} \mathrm{SO}_{4}-1 \mathrm{~g} / \mathrm{L}, \mathrm{MgSO}_{4} \cdot 7 \mathrm{H}_{2} \mathrm{O}-0.2 \mathrm{~g} / \mathrm{L}$, and the trace metals: EDTA-0.5 g/L, FeSO ${ }_{4} \cdot 7 \mathrm{H} 2 \mathrm{O}-0.2 \mathrm{~g} / \mathrm{L}$, $\mathrm{ZnSO}_{4} \cdot 7 \mathrm{H} 2 \mathrm{O}-0.01 \mathrm{~g} / \mathrm{L}, \mathrm{MnCl}_{2} \cdot 4 \mathrm{H}_{2} \mathrm{O}-0.003 \mathrm{~g} / \mathrm{L}, \mathrm{H}_{3} \mathrm{BO}_{3}-$ $0.03 \mathrm{~g} / \mathrm{L}, \mathrm{CoCl}_{2} \cdot 6 \mathrm{H}_{2} \mathrm{O}-0.02 \mathrm{~g} / \mathrm{L}, \mathrm{CuCl}_{2} \cdot 2 \mathrm{H}_{2} \mathrm{O}-0.001 \mathrm{~g} / \mathrm{L}$, $\mathrm{NiCl}_{2} \cdot 6 \mathrm{H}_{2} \mathrm{O}-0.002 \mathrm{~g} / \mathrm{L}, \mathrm{NaMoO}_{4} \cdot 2 \mathrm{H}_{2} \mathrm{O}-0.003 \mathrm{~g} / \mathrm{L}$. The final $\mathrm{pH}$ of the medium was 7 (Muñoz et al., 2007). Phenols and gallic acid, $50 \mathrm{mg} / \mathrm{L}$ each as a carbon source, were added to the MSM for growth of the new isolate. The cultures were incubated in an orbital shaker at $37^{\circ} \mathrm{C}$ and $100 \mathrm{rpm}$ for $24 \mathrm{~h}$.

\subsection{Growth kinetics and phenol/gallic acid biodegradation}

The bacterial strain isolated from the OMWW was evaluated for growth in the presence of either phenols or gallic acid (separately) as the sole carbon and energy source in order to characterize its potential for phenol/gallic acid biodegradation.

For the phenol biodegradation experiment, the isolate suspension was transferred to a set of sterile Erlenmeyer flasks with $100 \mathrm{~mL}$ MSM and different initial phenol (Alfa Aesar, UK) concentrations $(30,50,100$ and $200 \mathrm{mg} / \mathrm{L})$. All flasks were supplemented with an initial equal biomass of $\sim 0.144 \mathrm{CFU} / \mathrm{mL}$ (absorbance $\mathrm{A}_{600 \mathrm{~nm}} 0.018$ ). Sterile control flasks contained medium with the respective phenol concentration, without bacterial cells. All treatments and controls were performed in triplicate and incubated in an orbital shaker at $37^{\circ} \mathrm{C}$ and $100 \mathrm{rpm}$ (Lab centrifuge, MRC Ltd., Israel). In order to evaluate growth and degradation kinetics, the biomass growth was monitored by the

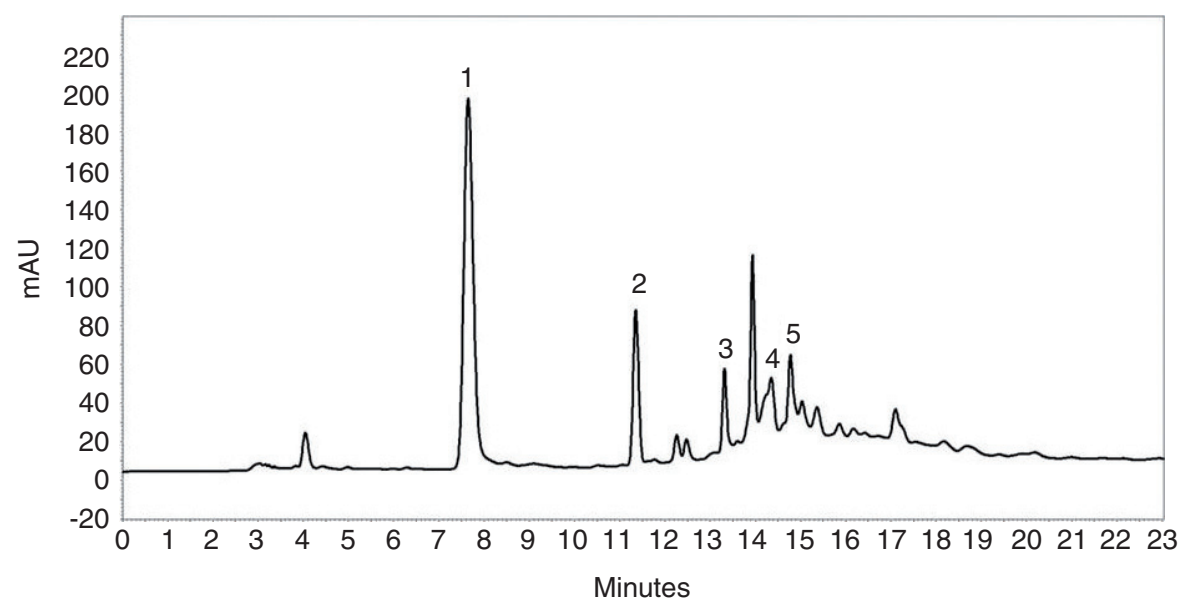

Figure 1. Chromatogram of the fresh s-TP fraction of OMWW at $280 \mathrm{~nm}$. Hydroxtyrosol (1), tyrososl (2), vanillic acid (3), ferulic acid (4), and p-coumaric acid (5). 
absorbance of the suspension at $600 \mathrm{~nm}$ (Ultrospec 2100 pro, Amersham Biosciences, USA) and phenol concentrations were determined at different time points using the direct spectrometric method with 4-aminoantipyrine (4-AAP) as a color reagent as described in detail in Rice et al., (2012). The method is based on a reaction between phenols and 4AAP in the presence of ferricyanide at $\mathrm{pH}$ 7.9. Absorbance was measured at $500 \mathrm{~nm}$.

The experimental setup for the gallic acid biodegradation experiment was identical to the phenol treatments, but with initial gallic acid concentrations of $25,50,100$ and $200 \mathrm{mg} / \mathrm{L}$ as the sole carbon source. Three replicates were performed for each gallic acid concentration and control. The samples were centrifuged and the supernatant was sampled at different time points for gallic acid measurement according to the Folin-Ciocalteau reagent (Sigma, Israel) method with gallic acid as the standard (10$100 \mathrm{mg} / \mathrm{L})$ (Azaizeh et al., 2015). The degradation kinetics of gallic acid were calculated in terms of $\%$ reduction.

\subsection{Screening for extracellular enzyme}

Pure cultures isolated from the OMWW were inoculated on skim milk agar plates (Fulzele et al., 2011), tributyrin nutrient agar plates, starch agar plates (Mishra and Behera, 2008) and tryptone yeast broth (Dalfard et al., 2006) for screening protease, esterase, amylase and laccase, respectively.

\subsection{Bacterial growth conditions for laccase production}

The OMWW isolate (Acinetobacter REY) was inoculated into Erlenmeyer flasks containing 100 $\mathrm{mL}$ of sterile tryptone yeast broth (TYB) containing $0.15 \%$ yeast extract (RM027, Himedia), $0.15 \%$ tryptone (Tryptone type-1 RM014, Himedia) and $0.5 \%$ sodium chloride as described earlier by Dalfard et al., (2006). The bacterial biomass was measured after $0,24,48,72 \mathrm{~h}$ under shaking $(100 \mathrm{rpm})$ at $37{ }^{\circ} \mathrm{C}$, as described above, and the culture supernatant was collected after centrifugation at $10000 \mathrm{rpm}$ for $10 \mathrm{~min}$ at $4{ }^{\circ} \mathrm{C}$ for extracellular laccase assay (Verma et al., 2016). In order to characterize the effect of inducers on laccase production by the isolate, treatments containing $200 \mu \mathrm{mol} / \mathrm{L} \mathrm{CuSO} \cdot 5 \mathrm{H}_{2} 0$ alone (Kuddus et al., 2013; Sondhi et al., 2015; Verma et al., 2016) and $200 \mu \mathrm{mol} / \mathrm{L} \mathrm{CuSO}_{4} \cdot 5 \mathrm{H}_{2} 0$ with 50 $\mathrm{mg} / \mathrm{L}$ phenols were performed. Sterile controls contained $100 \mathrm{~mL}$ of TYB (with and without inducer) without the addition of the isolate. All experiments were conducted in triplicate and the presented results are the average of three independent experiments.

\subsection{Extracellular laccase activity}

The enzyme assay was performed on the filtrate supernatant using 2,2'-azino-bis (3-ethylbenzothiazoline-6-sulphonic acid (ABTS) (Sigma, Israel) as the substrate for laccase activity, as described earlier (Tahmasbi et al., 2016), with some modifications. The per $\mathrm{mL}$ assay mixture consisted of 200 $\mu \mathrm{L}$ of crude extracellular filtrate (enzyme source) and $800 \mu \mathrm{L}$ aliquots of $1 \mathrm{mmol} / \mathrm{L}$ ABTS prepared in a $0.1 \mathrm{~mol} / \mathrm{L}$ sodium acetate buffer $(\mathrm{pH} 4.5)$ (Verma et al., 2016). The oxidation of ABTS was monitored by determining the increase in absorbance at 420 $\mathrm{nm}(\varepsilon 420,36000 \mathrm{~L} /(\mathrm{mol} . \mathrm{cm})$ at a path length of 1 $\mathrm{cm}$ ) after incubation at $32{ }^{\circ} \mathrm{C}$ for $10 \mathrm{~min}$. Blank samples were identical, except for the addition of $200 \mu \mathrm{L}$ of $0.1 \mathrm{~mol} / \mathrm{L}$ sodium acetate buffer ( $\mathrm{pH} 4.5)$ instead of the crude extracellular filtrate. All sampling and measurements were performed in triplicate. The change in absorbance in $10 \mathrm{~min}$ is equivalent to 1 $\mu \mathrm{mol} / \mathrm{L}$ of ABTS oxidized in $10 \mathrm{~min}$. The results were then converted to $1 \mu \mathrm{mol}$ of ABTS oxidized per min in order to calculate the International Units (IU). $1 \mathrm{U}$ is the amount of enzyme required to oxidize $1 \mu \mathrm{mol}$ of ABTS substrate per min. The laccase activity in $\mathrm{U} / \mathrm{mL}$ was calculated by the formula:

$$
\mathrm{EA}=\mathrm{A} \times \mathrm{V} / \mathrm{t} \times \varepsilon \times \mathrm{V}
$$

$$
\begin{aligned}
\text { Where } & \\
\mathrm{EA} & =\text { Enzyme activity }(\mathrm{IU}) \\
\mathrm{A} & =\text { Absorbance at } 420 \mathrm{~nm} \\
\mathrm{~V} & =\text { Total mixture volume }(\mathrm{mL}) \\
\mathrm{v} & =\text { Enzyme volume/Bacterial culture filtrate } \\
& (\mathrm{mL}) \\
\mathrm{t} & =\text { Incubation time }(\mathrm{min}) \\
\varepsilon & =\begin{array}{l}
\text { Extinction coefficient for ABTS }(36000 \mathrm{~L} / \\
(\text { mol } \mathrm{cm}))
\end{array}
\end{aligned}
$$

\section{RESULTS}

\subsection{Physico-chemical analysis of OMWW}

The fresh OMWW was analyzed according to standard methods (Rice et al., 2012). The parameters are shown in Table 1. The phenolic profile HPLC chromatogram of the main compounds of a fresh s-TP fraction of the OMWW is shown in Figure 1. The main compounds were found to be hydroxytyrosol, tyrosol, vanillic acid, ferulic acid, and p-coumaric acid.

\subsection{Isolation, 16S rRNA-based phylogeny and sequence accession}

The bacterial strain from the OMWW was found to be aerobic, Gram negative, with a rod-shaped morphology and non-motile (data not shown). The primary sequence alignment carried out by NCBI 
nucleotide blast search revealed that the OMWW isolate belongs to the Acinetobacter genus. A NJ analysis gave the phylogenetic position of this isolate closest to Acinetobacter pittii (Figure 2). The nucleotide sequence was submitted to GenBank, NCBI, and was assigned the accession number KY828225. For the purpose of current study, this isolate was named Acinetobacter REY.

\subsection{Phenol biodegradation}

The amount of phenol degraded and the kinetics of the process were studied at initial concentrations of $30,50,100$ and $200 \mathrm{mg} / \mathrm{L}$ which showed a complete depletion of phenols from the culture medium after $5,8,8$ and $10 \mathrm{~h}$, respectively (Figure 3 ). The results show that the higher the phenol concentration, the

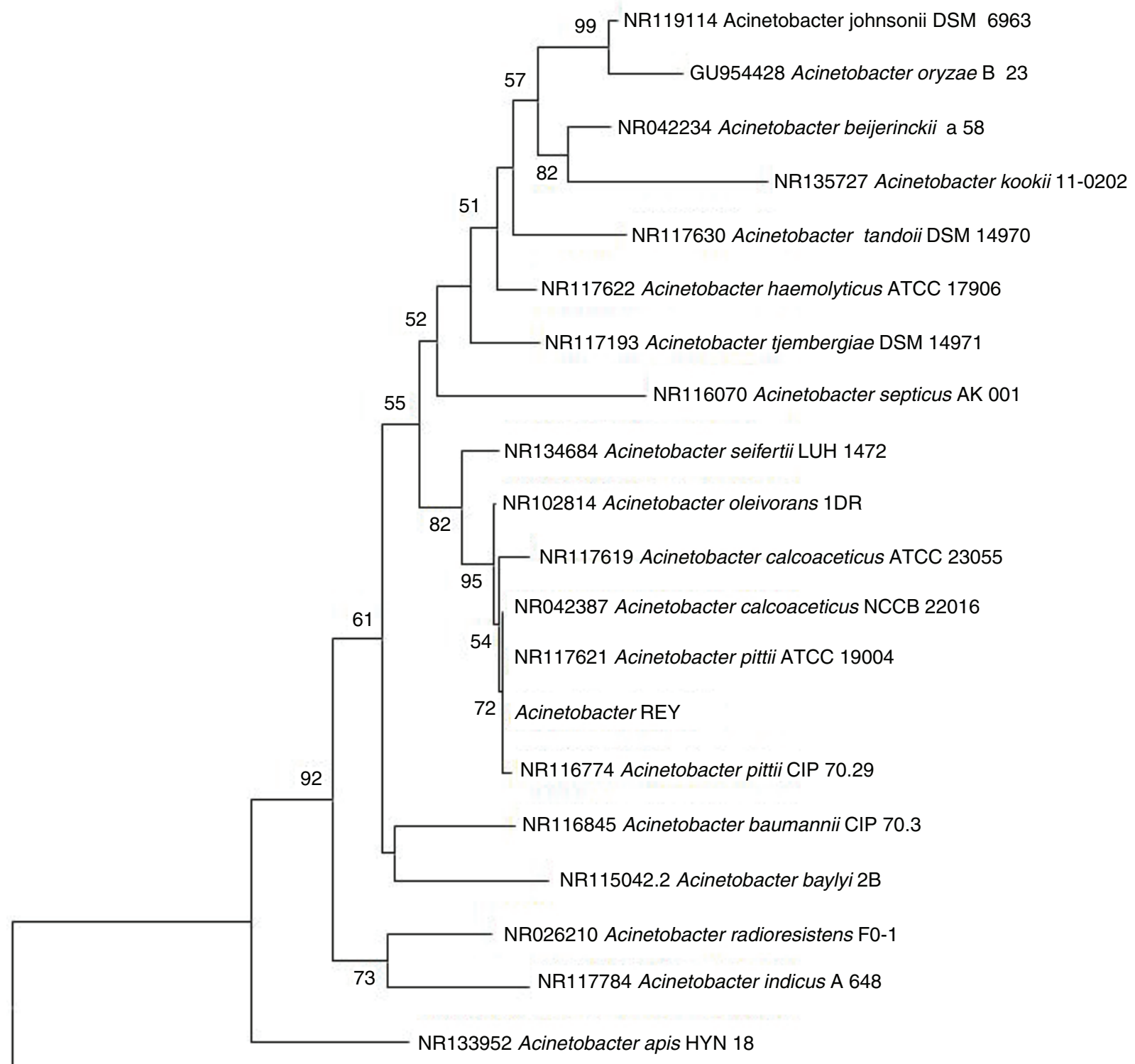

NR036825 Moraxella lacunata Morax260

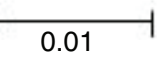

FIGURE 2. Neighbor-joining phylogenetic trees based on nearly complete 16S rRNA gene sequences of Acinobacter REY, an OMWW isolate, with closely related species from the genus Acinetobacter. Moraxella lacunata ATCC 17967 was used as an outgroup. The numbers at the nodes indicate the percentage of 1000 bootstrap replicates, values $>50 \%$ are presented. The scale bar represents 0.01 substitutions per nucleotide position. 


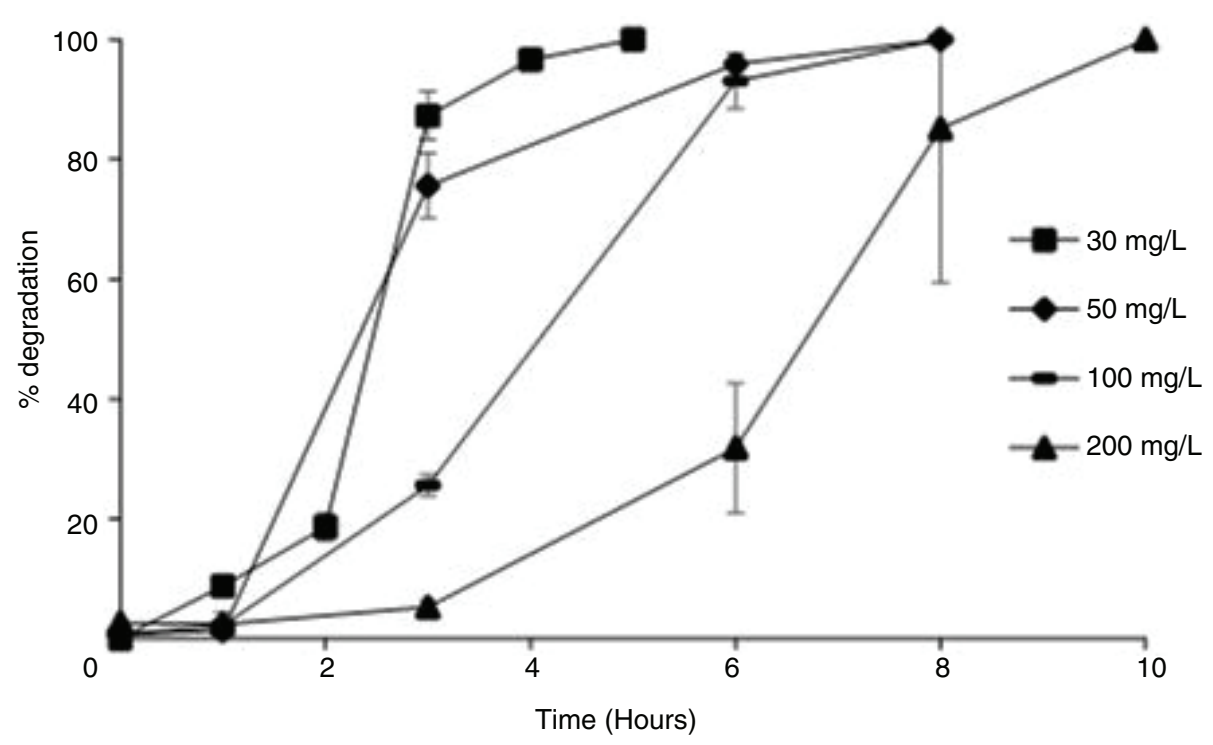

FIgURE 3. Kinetics of phenol degradation by Acinetobacter REY, an OMWW isolate

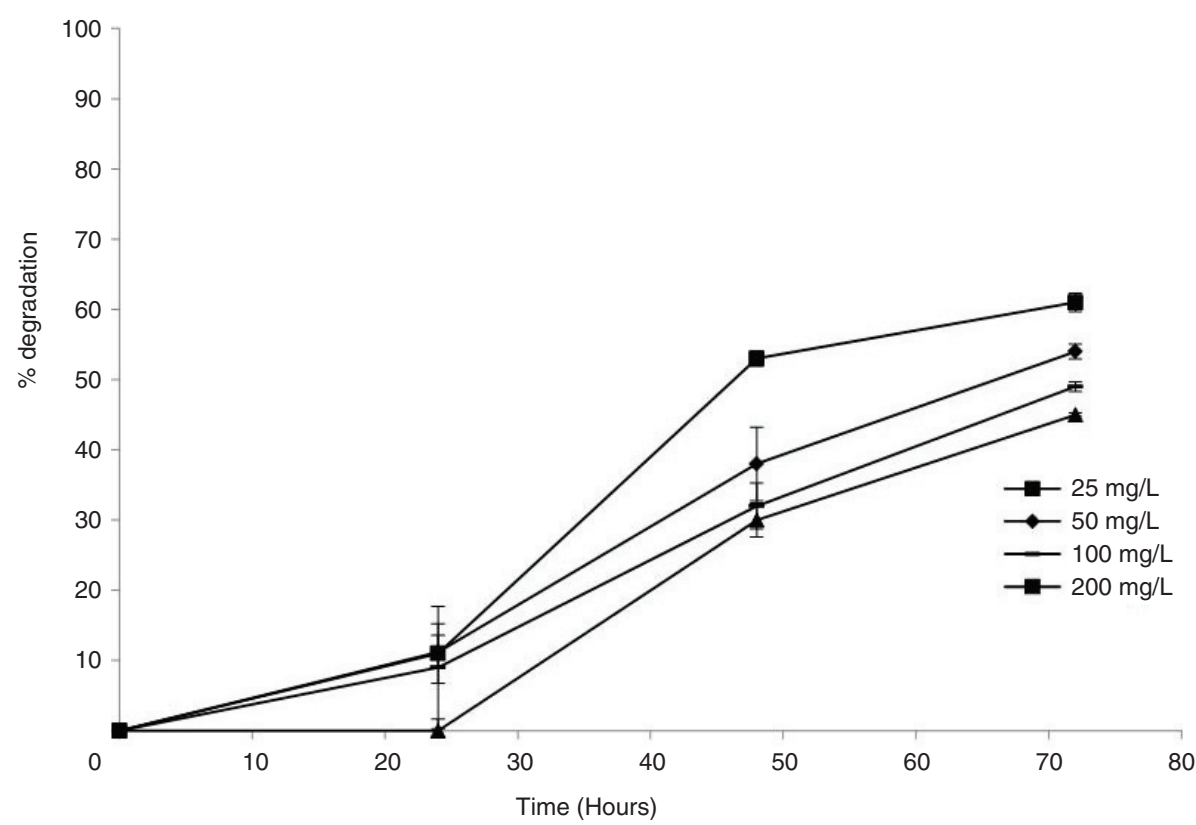

FIgURE 4. Kinetics of gallic acid degradation by Acinetobacter REY, an OMWW isolate

longer the time needed to fully degrade it, as found in many other studies, such as Marrot et al., (2006). The sterile control treatment did not exhibit any phenol loss due to abiotic adsorption or evaporation for all initial phenol concentrations (data not shown). This is in agreement with previous studies (Kurzbaum et al., 2010).

\subsection{Gallic acid biodegradation}

The bacterial strain Acinetobacter REY was tested for its gallic acid biodegradation kinetics. After $72 \mathrm{~h}$, there was a $60,55,50$ and $45 \%$ reduction of initial gallic acid concentrations of $25,50,100$ and $200 \mathrm{mg} / \mathrm{L}$, respectively (Figure 4). It was found that 


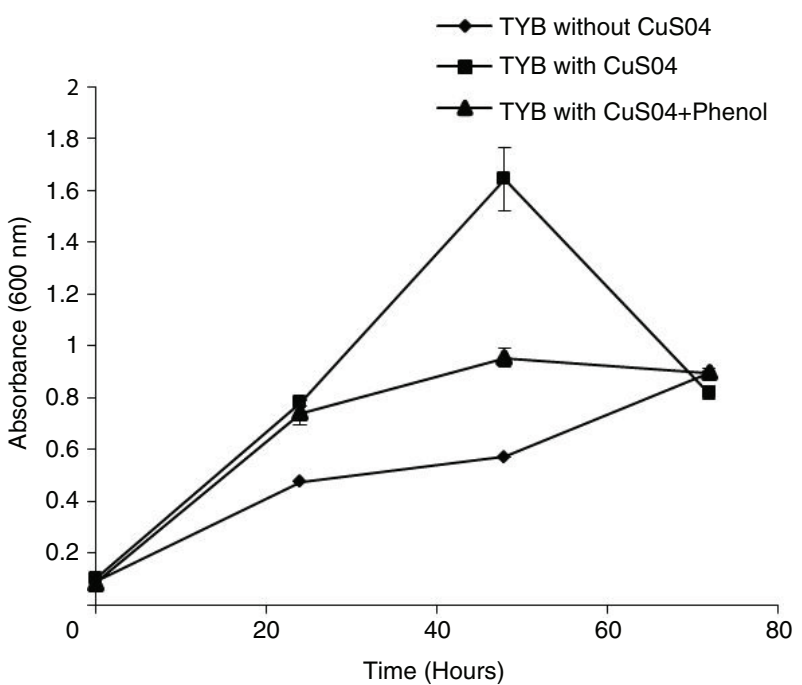

FIGURE 5. Bacterial growth in the presence and absence of the laccase inducers CuSO4 and phenols

increasing gallic acid concentrations decreased the degradation rate, indicating that Acinetobacter REY cells were susceptible to its antimicrobial action.

\subsection{Screening of the extracellular enzymes}

Amylase, lipase and protease were chosen for the screening due to their broad industrial applications. Interestingly, it was found that $A$. REY was negative for all three hydrolases based on the clear zone around the colony in starch agar plates, tributyrin nutrient agar plates and skim milk agar plates, respectively (not shown). However, $A$. REY extracellular laccase was found to be positive in tryptone yeast broth in the presence of a laccase inducer.

\subsection{Bacterial growth and extracellular laccase activity by $\mathrm{OMWW}$ isolate}

The extracellular laccase extraction assay was performed with known laccase inducers $\left(\mathrm{CuSO}_{4}\right.$ and phenol). Figure 5 shows a typical trend where the biomass increases with time. However, it also shows that biomass growth was relatively lower in the absence of laccase inducers compared with higher bacterial growth in the presence of the inducers CuSO4 and phenols and even higher in the presence of $\mathrm{CuSO} 4$ alone.

Figure 6 summarizes the laccase activity in the medium, which reached a maximum of 1.5 and $1.3 \mathrm{U} / \mathrm{mL}$ with the supplemented inducers $\mathrm{CuSO}_{4}$ and $\mathrm{CuSO}_{4}+$ phenols, respectively, after 48 h. At 72 $\mathrm{h}$, minor changes were noticed for both inducers. Without any inducer, a laccase activity of $0.65 \mathrm{U} /$ $\mathrm{mL}$ was found, which did not show any significant change over the $72 \mathrm{~h}$ of the experiment.

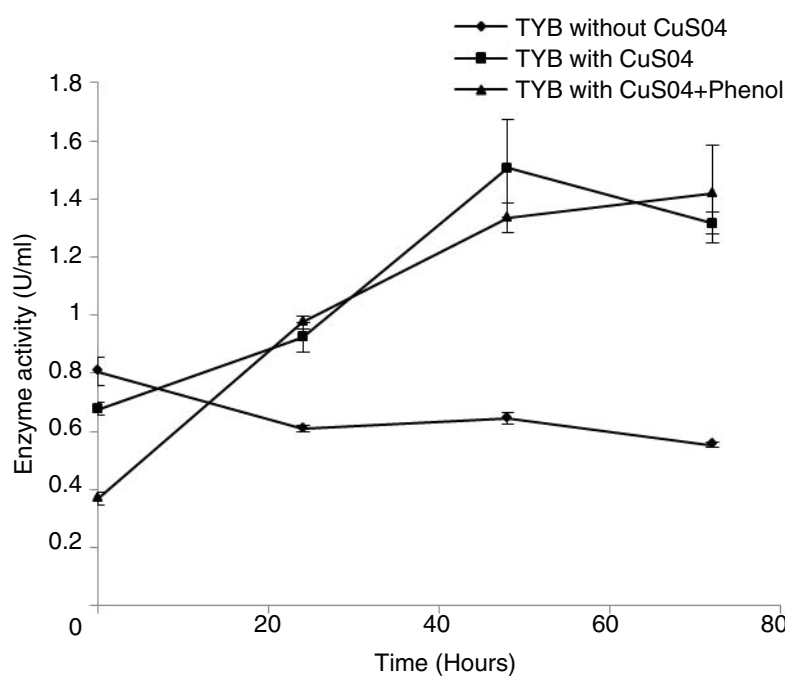

FIGURE 6. Laccase enzyme activity in the presence and absence of the laccase inducers CuSO4 and phenols

\section{DISCUSSION}

OMWW is one of the most polluting effluents produced by agro-food industries. It exhibits high toxicity to plants, bacteria, and aquatic organisms because of its organic substances (14-15\%) and phenolic compound (up to $10 \mathrm{~g} / \mathrm{L}$ ) contents (Tafesh et al., 2011). The organic compounds are measured as COD and phenolic content showed resistant to biodegradation. In addition, some are responsible for the OMWW's black color, depending on their state of degradation and the olive they come from (Tafesh et al., 2011). The OMWW was found to contain hydroxytyrosol, tyrosol, vanillic acid, ferulic acid, and p-coumaric acid as phenolics and a high load of COD, TSS and TKN both in the crude OMWW as well as in its s-TP fraction. The presence of Acinetobacter species in phenolicpolluted sites is very common and well documented (Table 2). Different sub-species of this bacterium are known for their ability to degrade different pollutants (Yuan et al., 2014). The 16S rRNA sequence analysis revealed that the OMWW isolate belongs to the Acinetobacter genus (and was named Acinetobacter REY) and is phylogenetically closest to Acinetobacter pittii.

Several authors reported on the phenol biodegradation efficacy of Acinetobacter species/strains. For example, Acinetobacter AQ5NOL 1 (Ahmad et al., 2012) has the ability to eliminate $1100 \mathrm{mg} / \mathrm{L}$ of phenols; Acinetobacter calcoaceticus PA (Liu et al., 2016) and Acinetobacter calcoaceticus var. anitratus (Cordova-Rosa et al., 2009) showed near complete removal of 800 and $400 \mathrm{mg} / \mathrm{L}$ of phenols in minimal media, respectively. In the current study, $A$. REY completely degraded phenols (200 mg/L) within 
TABLE 2. Different Acinetobacter sp. /strains and their phenol degradation efficacy.

\begin{tabular}{llll}
\hline Acinetobacter sp./strain & Phenol degradation efficacy & Source & Reference \\
\hline $\begin{array}{l}\text { A. calcoaceticus } \\
\text { var. anitratus }\end{array}$ & $100 \%$ degradation of $400 \mathrm{mg} / \mathrm{L}$ of phenols after $60 \mathrm{~h}$ & Industrial wastewater & $\begin{array}{l}\text { Cordova-Rosa } \text { et al. } \\
2009\end{array}$ \\
AQ5NOL 1 & $100 \%$ degradation of $1100 \mathrm{mg} / \mathrm{L}$ phenols at $240 \mathrm{~h}$ & Local site & Ahmad et al. 2012 \\
$\begin{array}{ll}\text { A. Calcoaceticus } \text { PA } \\
\text { A. REY }\end{array}$ & $91.6 \%$ degradation of $800 \mathrm{mg} / \mathrm{L}$ phenols within $48 \mathrm{~h}$ & Phenolic Wastewater & Liu et al. 2016 \\
\hline
\end{tabular}

$10 \mathrm{~h}$ and at this concentration, a lag phase of up to 3 $\mathrm{h}$ was observed. The main reason for this is probably the phenols' toxicity. Similar results were observed in a study by Bakhshi et al., (2011) and suggest that high phenol concentrations might have an inhibitory effect on microbial growth.

It is shown that $A$. REY degraded gallic acid slowly with incubation times below $24 \mathrm{~h}$ (less than $10 \%$ from the initial concentration). Nevertheless, $48 \mathrm{~h}$ or more after inoculation, all four gallic acid concentrations $(25,50,100$ and $200 \mathrm{mg} / \mathrm{L})$ underwent substantial degradation, providing compelling evidence that gallic acid can be degraded by the biomass given sufficient time for biodegradation, thus overcoming the inhibitory effect to a certain extent. This slow biodegradation kinetics of gallic acid is evidence for the relatively slow treatment process obtained in OMWW treatment plants no need to write compared to domestic waste water treatment plants. Furthermore, Figure 4 shows a $45 \%$ degradation of the initial $200 \mathrm{mg} / \mathrm{L}$ gallic acid at $72 \mathrm{~h}$ by $A$. REY, and that the gallic acid concentration is inversely correlated with the degradation rate. This indicates that $A$. REY cells were susceptible to antimicrobial action. This finding strongly supports the work of Borges et al., (2013) who showed that phytochemical constituents (for example gallic acid, tannic acid, ferulic acid and others) are antimicrobials, based on susceptibility tests that produced inhibitory concentrations in the range of 100-1000 mg/L. Borges et al., (2013) reported a minimal inhibitory concentration of gallic acid of $500 \mathrm{mg} / \mathrm{L}$ for Pseudomonas aeruginosa. However, our studies showed that $A$. REY tolerates gallic acid up to a concentration of $200 \mathrm{mg} / \mathrm{L}$ only.

The OMWW isolate was also screened for extracellular enzyme production and was found to be lipase, protease and amylase negative. However, it was shown to produce laccase, which can transform phenolic compounds and accelerate degradation processes. Our study confirmed that this isolate was able to secrete extracellular laccase, showing such a feature in an isolate obtained from an OMWW for the first time. However, the intracellular laccase production of $0.019 \mathrm{U} / \mathrm{mg}$ of protein/min after $48 \mathrm{~h}$ was reported in $A$. calcoaceticus (Ghodake et al., 2011). The laccase activity of the new isolate, $A$. REY, showed extracellular laccase activity $(1.5 \mathrm{U} / \mathrm{mL})$ that was almost identical to a pure bacterial strain of Streptomyces cyaneus that exhibited $2 \mathrm{U} / \mathrm{mL}$ (Margot et al., 2013). Staphylococcus saprophyticus (Mongkolthanaruk et al., 2012) and Providencia rettgeri HSL1 (Lade et al., 2015) were also reported as laccase producers, with lower laccase activity than $A$. REY. Many bacterial strains, for example Bacillus tequilensis SN4 (Sondhi et al., 2015), Pseudomonas putida MTCC 7525 (Kuddus et al., 2013) and Streptomyces sviceus (Suljić et al., 2015), have been reported to have higher laccase activity. Studies showed that bacterial laccase was used in the bioremediation of dye and micropollutants (Kuddus et al., 2013; Margot et al., 2013). However, little is known about the enzymatic phenol degradation which will be the future scope of our study, in order to develop an efficient bio-resource for the de-phenolization of organic matter containing high loads of polyphenols such as those found in OMWW.

\section{CONCLUSIONS}

In the present study, the isolation and identification of a novel laccase producing bacterial strain is presented, as the first step for the utilization of this enzyme in bio-remedial applications. Not only $A$. REY showed biodegrability of phenols and gallic acid $(200 \mathrm{mg} / \mathrm{L})$. A constitutive production of extracellular laccase, with an activity of 1.5 and 1.3 U/mL, was also found with the supplemented inducers of $\mathrm{CuSO}_{4}$ and $\mathrm{CuSO}_{4}+$ phenosl, respectively This bacterium is thus a promising candidate for the efficient removal of phenolic compounds in phenol-rich wastewater, especially in OMWW, for which there is no satisfactory or cost-effective treatment. In future research, we will attempt to evaluate the efficacy of extracellular laccase as a pretreatment in OMWW bio-remediation, in order to protect the digestive biomass from high concentrations of phenolic compounds. It is assumed that a reduction in the phenolic concentration will enable the development of much better aerobic conditions in the OMWW medium, thus substantially increasing the biodegradation rate. This is expected to improve the quality of the effluent. The use of extracellular 
laccase presents a potential horizon for the successful aerobic treatment of waste water effluents.

\section{ACKNOWLEDGMENTS}

Financial assistance to one of the authors (RK) by the Israel Government Scholarship under the Ministry of Human Resource Development (MHRD) and by the Government of India is thankfully acknowledged.

\section{REFERENCES}

Ahmad SA, Shamaan NA, Arif NM, Koon GB. 2012. Enhanced phenol degradation by immobilized Acinetobacter sp. strain AQ5NOL 1. World J. Microbiol. Biotechnol. 28, 347-352. https://doi.org/10.1007/s11274-011-0826-z

Atalla MM, Zeinab HK, Eman RH, Amani AY. 2013. Characterization and kinetic properties of the purified Trematosphaeria mangrovei laccase enzyme. Saudi J. Biol. Sci. 20, 373-381. https://doi.org/10.1016/j. sjbs.2013.04.001

Azaizeh H, Halahlih F, Najami N, Brunner D. 2012. Antioxidant activity of phenolic fractions in olive mill wastewater. Food Chem. 134, 2226-2234. https://doi. org/10.1016/j.foodchem.2012.04.035

Azaizeh H, Kurzbaum E, Said O, Jaradat H. 2015. The potential of autochthonous microbial culture encapsulation in a confined environment for phenol biodegradation. Environ. Sci. Pollut. Res. Int. 22, 15179. https://doi. org/10.1007/s11356-015-4981-x

Bakhshi Z, Najafpour G, Kariminezhad E, Pishgar R. 2011. Growth kinetic models for phenol biodegradation in a batch culture of Pseudomonas putida. Environ. Technol. 32, 1835-1841. https://doi.org/10.1080/09593330.2011.56 2925

Baldrian P, Šnajdr J. 2006. Production of ligninolytic enzymes by litter-decomposing fungi and their ability to decolorize synthetic dyes. Enzyme Microb. Technol. 39, 1023-1029. https://doi.org/10.1016/j.enzmictec.2006.02.011

Bertand B. 2013. Fungal laccases: induction and production. Rev. Mex. Ing. quimica 12, 473-488.

Borges A Ferreira C Saavedra MJ, Simoes M. 2013. Antibacterial activity and mode of action of ferulic and gallic acids against pathogenic bacteria. Microb. Drug Resist. 19, 256-265. https://doi.org/10.1089/ mdr.2012.0244

Cordova-Rosa SM, Dams RI, Cordova-Rosa EV, Radetski MR. 2009. Remediation of phenol-contaminated soil by a bacterial consortium and Acinetobacter calcoaceticus isolated from an industrial wastewater treatment plant. J. Hazard. Mater. 164, 61-66. https://doi.org/10.1016/j. jhazmat.2008.07.120

Dalfard AB, Khajeh K, Soudi MR, Naderi-Manesh H. 2006. Isolation and biochemical characterization of laccase and tyrosinase activities in a novel melanogenic soil bacterium. Enzyme Microb. Technol. 39, 1409-1416. https:// doi.org/10.1016/j.enzmictec.2006.03.029

Edgar RC. 2004. MUSCLE: multiple sequence alignment with high accuracy and high throughput. Nucleic Acids Res. 32, 1792-1797. https://doi.org/10.1093/nar/gkh340

Fulzele R, Desa E, Yadav A, Shouche Y. 2011. Characterization of novel extracellular protease produced by marine bacterial isolate from the Indian Ocean. Brazilian $J$. Microbiol. 42, 1364-1373. https://doi.org/10.1590/ S1517-83822011000400018

Ghodake G, Jadhav U, Tamboli D, Kagalkar A. 2011. Decolorization of Textile Dyes and Degradation of Mono-Azo Dye Amaranth by Acinetobacter calcoaceticus NCIM 2890. Indian J. Microbiol. 51, 501-508. https:// doi.org/10.1007/s12088-011-0131-4
Iasur-Kruh L, Hadar Y, Minz D. 2011. Isolation and bioaugmentation of an estradiol-degrading bacterium and its integration into a mature biofilm. Appl. Environ. Microbiol. 77, 3734-40. https://doi.org/10.1128/ AEM.00691-11

Kuddus M, Joseph B, Wasudev Ramteke P. 2013. Production of laccase from newly isolated Pseudomonas putida and its application in bioremediation of synthetic dyes and industrial effluents. Biocatal. Agric. Biotechnol. 2, 333-338. https://doi.org/10.1016/j. bcab.2013.06.002

Kumar S, Stecher G, Tamura K. 2016. MEGA7: Molecular evolutionary genetics analysis version 7.0 for bigger datasets. Mol. Biol. Evol. 33, 1870-1874. https://doi. org $/ 10.1093 / \mathrm{molbev} / \mathrm{msw} 054$

Kunamneni A, Camarero S, García-Burgos C, Plou FJ. 2008. Engineering and Applications of fungal laccases for organic synthesis. Microb. Cell Fact. 7, 32. https://doi. org/10.1186/1475-2859-7-32

Kurzbaum E, Kirzhner F, Sela S, Zimmels Y. 2010. Efficiency of phenol biodegradation by planktonic Pseudomonas pseudoalcaligenes (a constructed wetland isolate) vs. root and gravel biofilm. Water Res. 44, 5021-5031. https://doi. org/10.1016/j.watres.2010.07.020

Lade H, Govindwar S, Paul D. 2015. Low-cost biodegradation and detoxification of textile azo dye C.I. Reactive Blue 172 by Providencia rettgeri Strain HSL1. J. Chem. 2015, 1-10. https://doi.org/10.1155/2015/894109

Liu Z, Xie W, Li D, Peng Y. 2016. Biodegradation of phenol by bacteria strain Acinetobacter Calcoaceticus PA isolated from phenolic wastewater. Int. J. Environ. Res. Public Health 13, 1-8. https://doi.org/10.3390/ ijerph 13030300

Margot J, Bennati-Granier C, Maillard J, Blanques P. 2013. Bacterial versus fungal laccase: potential for micropollutant degradation. $A M B$ Express 3, 1-14. https://doi. org/10.1186/2191-0855-3-63

Marrot B, Barrios-Martinez A, Moulin P, Roche N. 2006. Biodegradation of high phenol concentration by activated sludge in an immersed membrane bioreactor. Biochem. Eng. J. 30, 174-183. https://doi.org/10.1016/j. bej.2006.03.006

Mishra S, Behera N. 2008. Amylase activity of a starch degrading bacteria isolated from soil receiving kitchen wastes. African J. Biotechnol. 7, 3326-3331.

Mongkolthanaruk W, Tongbopit S, Bhoonobtong A. 2012. Independent behavior of bacterial laccases to inducers and metal ions during production and activity. African $J$. Biotechnol. 11, 9391-9398.

Muñoz R, Díaz LF, Bordel S, Villaverde S. 2007. Inhibitory effects of catechol accumulation on benzene biodegradation in Pseudomonas putida F1 cultures. Chemosphere 68, 244-252. https://doi.org/10.1016/j. chemosphere.2007.01.016

Muthukumar NP, Murugan S. 2014. Production, purification and application of bacterial laccase: A Review. Biotechnology 13, 196-205. https://doi.org/10.3923/ biotech.2014.196.205

Rice EW, Baird RB, Eaton AD, Clesceri LS. 2012. Standard Methods for the Examination of Water and Wastewater. American Public Health Associasion.

Ruiz JC, De la Rubia T, Pérez J, Martinez Lopez, J. 2002. Effect of olive oil mill wastewater on extracellular ligninolytic enzymes produced by Phanerochaete flavido-alba. FEMS Microbiol. Lett. 212, 41-45. https://doi.org/10.1016/ S0378-1097(02)00683-3

Sondhi S, Sharma P, George N, Chauhan PS. 2015. An extracellular thermo-alkali-stable laccase from Bacillus tequilensis SN4, with a potential to biobleach softwood pulp. 3 Biotech. 5, 175-185. https://doi.org/10.1007/ s13205-014-0207-z

Suljić S, Mortzfeld FB, Gunne M, Urlacher VB. 2015. Enhanced biocatalytic performance of bacterial laccase from Streptomyces sviceus: Application in the Michael addition sequence towards 3-Arylated 4-Oxochromanes. 
10 • R. Kumar, Y. Raizner, L.I. Kruh, O. Menashe, H. Azaizeh, S. Kapur and E. Kurzbaum

Chem. Cat. Chem. 7, 1380-1385. https://doi.org/10.1002/ cctc. 201500142

Tafesh A, Najami N, Jadoun J, Halahlih F. 2011. Synergistic antibacterial effects of polyphenolic compounds from olive mill wastewater. Evid. Based. Complement. Alternat. Med. 2011, 1-9. https://doi. org/10.1155/2011/431021

Tahmasbi H, Khoshayand MR, Bozorgi-Koushalshahi M, Heidary M. 2016. Biocatalytic conversion and detoxification of imipramine by the laccase-mediated system. Int
Biodeterior: Biodegradation 108, 1-8. https://doi. org/10.1016/j.ibiod.2015.11.029

Verma A, Dhiman K, Shirkot. 2016. Hyper-production of laccase by Pseudomonas putida LUA15.1 through mutagenesis. J. Microbiol. Exp. 3, 1-8. https://doi.org/10.15406/ jmen.2016.03.00080

Yuan H, Yao J, Masakorala K, Wang F. 2014. Isolation and characterization of a newly isolated pyrene-degrading Acinetobacter strain USTB-X. Environ. Sci. Pollut. Res. 21, 2724-2732. https://doi.org/10.1007/s11356-013-2221-9 